\title{
CHAPTER 1 \\ PENSION SYSTEM AS A GLOBAL PROBLEM AND SUBJECT OF GLOBAL STUDY
}

\section{Barannik L. B.}

\section{INTRODUCTION}

The system of pension provision of the population, or simply pension benefits, is of interest for not only scientists and politicians but also ordinary people. This interest has close character because the pensioning has grown into a global financial problem. The pension system (hereinafter referred to as PS) is the subject of study of scientists, economists, practices both in the world and in Ukraine, which is not accidental. Among the major research on pension provision development, the works of scientists for different periods should be noted. A classic of the genre is undoubtedly the report of the Rome Club scientists titled "Borders of Growth" and other works aimed at solving current problems by developing a new direction in their study, known as global modelling ${ }^{1}$. Under the globalization challenges influence, many works are devoted to the functioning of pension systems in different countries. E. Whitehouse collected and systematized data on pension systems operating in 53 countries of the world ${ }^{2}$. Kotlikoff and Burns analysed the deep structural deficiencies of modern pension provision systems in developed countries, in particular, in the United States. The authors suggest a set of political measures that will, if not prevent the coming storm, at least mitigate its impact, as well as provide recommendations to ordinary citizens on the preservation of personal savings in a virtually inevitable financial crisis ${ }^{3}$.

The development of pension issues in many scientific studies is closely linked with the analysis of political and globalization processes

\footnotetext{
${ }^{1}$ Meadows, D. H., Meadows, D. L., Randers, J., \& William, W. Behrens III (1972). The limits to growth. A Report for the Club of Rome's Project on the Predicament of Mankind (211 p.). New York: Universe Books.

${ }^{2}$ Whitehouse, E. (2007). Pension Panorama: Retirement-Income Systems in 53 Countries (234 p.). Washington, DC: The World Bank. Retrieved from: http://www.biomedsearch.com/article/ Edward Whitehouse-Pension-PanoramaRetirement/210033207.html

${ }^{3}$ Kotlikoff, L., \& Burns, S. (2005). Pensionnaya sistema pered burey: to, chto nuzhno znat kazhdomu o finansovom budushchem svoyey strany [Pension system before the storm: what you need to know about each other about the financial future of your country] (348 p.). Translated from English. Moscow: Alpina Biznes Buks.
} 
(Pension Reform in Europe). Gugushvili in his monograph summarizes the experience of the formation and development of pension systems in 23 countries of Central and Eastern Europe, the independent states that arose in the territory of the former USSR in 1989-1997. The author concluded that in these countries, economic indicators, change in demographic background, internal political struggle, and external influence became the main reasons for the transformation of pension system models. Surhone, Russell, Kaplan, and Hannon examined the legislative basis of pension provision in China, India, Brazil, and described the investment processes of pension savings, the relationship between enterprises and trade unions, considered the mechanisms that allowed pension systems to survive economic cataclysms ${ }^{4}$.

Issues of pension provision in the context of social and economic development of Ukraine after gaining state sovereignty are researched in the works of domestic scientists and practitioners, namely L. Barannik, B. Zaychuk, E. Libanova, I. Lunina, O. Makarova, B. Nadtochii, D. Polozenko, M. Rippa, V. Skurativskyi, L. Tkachenko, V. Tropina, I. Chugunov, S. Yurii, and others. It is worth noting a number of authors and their work.

Problems, which are seriously identified in the pensioning, attributed to a number of factors, including the growing trend of the modern society ageing; disproportion between economically active population and pensioners; unemployment, inefficient models of social protection for elderly people, highly active labour migration; economic downturns; an increase in local/global dichotomy uncertainty, which complicates the reforming national pension systems. These trends are global in nature and affect more or less all countries of the world. They have a negative impact, primarily, on the systems of social protection of the population in substantially all civilized states, especially on the pension provision for citizens. The way out of this situation was initially the practice of financing pensions and other social guarantees at the expense of state budgets. However, this approach does not work in favour of long-term sustainable development.

Currently, in most developed countries, an affordable model of pension provision is a three-tier pension system, based on several forms of pension payment financing. World experience suggests that after the

\footnotetext{
${ }^{4}$ Akbulatov, R. S. (2013). Istoriya stanovleniya i razvitiya pensionnoy sistemy Krasnoyarskoyo kraya $v$ 90-e gg. XX v. - nachalo XXI v. [The history of the formation and development of the pension system of the Krasnoyarsk Territory in the 90 s. XX - the beginning of the XXI century]. Thesis. Irkutsk.
} 
introduction of such a system, some countries have made significant advances in the pension provision for their citizens, despite global challenges.

This experience is extremely useful for countries in transition, including Ukraine, which creates its own PS, and where $30 \%$ of the country's population is retired. Ukraine is not isolated from globalization processes and is influenced by the same way as other countries. However, ageing of the population is not supported by significant changes in solving problems such as low fertility, labour outflows, and high mortality in working age, etc.

Unfortunately, the problem of poor pension provision is compounded by the internal political and economic crisis and the military conflict of geopolitical nature. Consequently, these points indicate the relevance of studying the globalization trends impact on the effective pension provision.

\subsection{Historical and theoretical aspects of the development of pensions in the world}

When Julius Caesar introduced the military pension system in Rome, he was hardly aware of the fact that he was setting a precedent that would seriously increase the financial difficulties of the Roman Empire in a few centuries. The history of the modern pension system is the most ambitious example of such a decision on influencing public finances and social development. Pension systems began to appear massively in Europe and its colonies in the late 19th - early $20^{\text {th }}$ centuries. Historically, the first legally organized PS appeared in Germany. In 1889, the Reichstag adopted a law on retirement benefits according to age or disability. Soon, other European countries introduced old-age insurance and passed a number of laws on social protection of the population ${ }^{5}$. At that time, the revolutionary events in the countries of Western Europe in the second half of the 19th century were the impetus of social reforms. In some countries, insurance was called "in case of illness", and health laws were adopted separately in different regions. Social insurance, 8-hour working day, paid leave; extended trade union

\footnotetext{
Antropov, V. V. (2006). Sotsyalnaya zashchita v stranakh Evropeyskogo Soyuza. Istoriya, organizatsiya, finansirovaniye, problemy [Social protection in the European Union. History, organization, financing, problems] (271 p.). Moscow: Izdatelstvo Ekonomika; Tserkasevich, L. V. (2002). Sovremennyye tendentsii sotsialnoy politiki $v$ stranakh Evropeyskogo Soyuza [Modern trends in social policy in the European Union] (245 p.). St. Petersburg: SPb HEUF.
} 
rights, etc. were introduced. A characteristic feature of the German approach was that social insurance was compulsory and based on contributions paid by both employers and workers. The German system based on the previous practice of voluntary mutual funds, organized by guilds and labour unions. The pension rights in the new system were based on previously paid contributions.

Denmark (1891) and New Zealand (1898) introduced a "system of retirement" focused on targeted assistance to the poor, it was funded by general tax fees, provided for scrutiny of needs and it guaranteed insignificant levels of payments. These pension systems are more likely to derive from traditional laws on the poor ${ }^{6}$. The system of pension insurance was introduced as a mechanism that guarantees substantive possibility in case of living into the non-working age.

In the first half of the 20th century, many countries have created national pension systems based on the principle of solidarity between generations, and in the second half of the 20th century, they also passed the laws on the minimum guaranteed income. Despite all this, the civilized world still tries to organize the system of social protection of the elderly properly, though the reasons are already hidden in another.

First of all, these are negative demographic processes. At the beginning of the 21 st century, practically the whole industrialized world has shown a birth rate below the estimated level required for simple reproduction of the population -2.1 children per woman at procreative age. In 2000, the world's population was 6.03 billion people (which is 4.4 billion more than in 1930, and 2.5 billion more than in 1950), in $2010-$ 6.7 billion people. According to experts, by 2050, the population of the planet will reach 9.3 billion, and then stabilize at 10.5-11.0 billion people. Demographic processes are at an uneven pace. The slowdown in the growth rate of the planet's population is expected to be $0.9 \%$ on average per year. In developed countries, average annual growth rates will drop to $0.36 \%$, compared to $0.6 \%$ over the past 25 years. In developing countries, the population will grow by $18 \%$, an average of $1.1 \%$ per year?

However, in some of these countries, low living standards and a lack of health care systems, high mortality, and some others are critical

\footnotetext{
${ }^{6}$ Haidar, E. (2004). Istoriya pensiy [The history of pensions]. URL: http://www.ng.ru/ideas/2004-0713/10_histori.html

${ }^{7}$ Dynkin, A. A. (Ed.) (2007). Mirovaya ekonomika: prognoz do 2020 goda [World Economy: Forecast until 2020] (429 p.). Moscow: Mahistr; Bilorus, O., \& Matseiko, Yu. (2002). My mohly b buty sered lideriv [We could be among the leaders]. Holos Ukrainy, March 1, 6.
} 
demographic factors that slow down their development. Increasing the standard of living of people in economically developed countries has led to an increase in life expectancy and a decline in fertility. Active migration processes also had some negative consequences, which resulted in a significant reduction in the number of workers in some European countries, and an increase in the burden on the working part of the population. It turned out that the solidarity system of pension provision is too dependent on demographic problems and is not able to solve the entire complex of urgent socio-economic problems. The changes in the demographic structure of European countries at the end of the $20^{\text {th }}$ century in the direction of an increase in the proportion of people over the age of 65 in the total population forced the governments of these countries to increase public expenditures for social needs and pension provision ${ }^{8}$.

Dr. David Knox, the Senior Partner of the Melbourne Mercer Global Pension Index, says that pension systems around the world, including social security systems and private sector arrangements, are now under more pressure than ever before. Significant ageing of the population in many countries is a fact. "Yet this is not the only pressure point on our pension systems. Others include: the low-growth/low-interest economic environment which reduces the long-term benefit of compound interest, particularly affecting defined contribution arrangements; the increasing prevalence of defined contribution schemes and the related increased responsibility on individuals to understand the new arrangements; the lack of easy access to pension plans in both developed and developing economies, whether it be due to informal labour markets or the growing importance of "gig employment"; government debt in some countries which affects the ability to pay benefits in pay-as-you-go systems while high household debt in other countries will affect the long term adequacy of the benefits provided; the need to develop sustainable and robust income products as retirees seek more control and flexibility over their financial affairs"?.

"As significant pension reform is being considered or implemented in many countries, it is important that we learn together to understand what best practice may look like, both now and into the future" 10 .

\footnotetext{
${ }^{8}$ Tanzi, V., \& Schuknecht, L. (2000). Public Spending in the 20th Century. A Global Perspective. Cambridge and New York: Cambridge University Press.

9 Melbourne Mercer Global Pension Index 2018. P. 3. URL: https://australiancentre.com.au/wpcontent/uploads/2018/10/MMGPI-Report-2018.pdf

${ }^{10}$ Ibid.
} 
In addition, measures of many governments have been taken to stimulate the birth rate by providing more material assistance to families at the birth of a child; increase in leave due to pregnancy and childbirth; introduction of social security for migrants, refugees, people with disabilities in the national systems of social protection of the population (hereinafter referred to as the SPP); attracting foreign skilled workers to the country. In Germany alone, from 1960 to 1973, their number increased from 686 thousand to 2.6 million people ${ }^{11}$.

By the start of World War II, almost all industrialized countries had pension systems, some of them were limited according to the proportion of the population covered by pension protection. The decades after World War II were a time of unprecedented expansion of the level of pension payments coverage in most developed countries. However, active subsidization of the PS from the state budget took funds from other sectors of the economy, which hindered the country's development. So at the end of the 20th century, pension reforms have begun in almost all countries of the world. Their goal was to create a national pension system that would take into account economic, political, and socio-demographic changes in their own countries and in the world as a whole. Those countries that timely found the problems and estimated the implications for the state budgets began pension reforms to find new sources of funding and new organizational and legal principles.

Pension system reforming occurred as a modernization of the distribution pension system without the introduction of accumulative principles, implementation of the transition to cumulative schemes and a sharp restriction in this distribution sector, as well as the adoption of a variant that combines distribution and accumulation principles. The third variant was chosen by the majority of developed and developing countries. It is based on the introduction of an individual accounts system with obligatory and voluntary contributions. The latter is called the accumulative pension system since it is based on the capitalization of contributions for future retirement.

The world experience of pension reforms has shown that a cumulative system is more acceptable since it contributes to an increase in aggregate national savings, and hence to economic growth; does not depend on demographic risks, which jeopardize the development of the

\footnotetext{
${ }^{11}$ Karachurina, L. (2009). Germanyia: kak upravliat migrantami [Germany: how to manage migrants]. Sovremennaya Yevropa, 2, 18-33.
} 
distribution system; provides a sufficient level of pensions differentiation depending on earnings and the efficiency of using retirement savings ${ }^{12}$. In theory, the liberal model of social policy has prevailed, which is based on the subsidiarity and self-financing principles, in other words, it is the economic doctrine of minimal state interference in the social sphere.

Earlier it was considered that retirement is possible only at the expense of two financial methods of accumulation of funds. Otto Bismarck formulated one of the first concepts of retirement provision. He considered the system of pensions as a system of material protection of workers and their family members in old age and in the case of disability, in which the amount of the assistance provided should be consistent with the duration of payment of contributions to the pension fund. That is, it refers to social insurance, including pension insurance. According to W. Beveridge's concept, the system of pensions is a system of material protection of citizens, in which all persons at the age of reaching a minimum amount of material assistance (minimum pension) financed from the state tax revenues are provided. Today there are much more options for financing pensions. There is an active search for effective pension insurance models in the world.

The reform of the pension system by many European countries is aimed at ensuring its future sustainability. In the case of an unbalanced pension system, the increase in retirement benefits caused by the aging population will lead to an increase in expenditures from the state budget, which remains one of the main sources of coverage of the deficit of the pension fund. According to experts, this part of government spending in OECD countries will increase from $9.3 \%$ of GDP in 2010 up to $11.7 \%$ of GDP by $2050^{13}$.

Among the primary measures to change the financial mechanism of retirement - the transition to a multilevel pension system. It is known, the International Labour Organization and the European Union use the classification of pension systems based on the "three-tiered" system and reflect the role of different actors in providing retirement income. The current classification of the World Bank includes five levels of the pension system.

\footnotetext{
${ }^{12}$ Ivanova, E. I., \& Sidornia, A. A. (2014). Mirovoy opyt razvitiya pensionnykh sistem: obshchemirovyye tendentsii i mezhstranovyye razlichiya [World experience in the development of pension systems: global trends and differences between countries]. Molodezhnyy nauchnyy forum: Obshchestvennyye $i$ ekonomicheskiye nauki. URL: https://nauchforum.ru/studconf/social/viii/23188

${ }^{13}$ Pensions at a Glance 2013. OECD and G20 Indicators. URL: https://www.oecd-ilibrary.org/financeand-investment/pensions-at-a-glance-2013_9791195073054-ko
} 
Zero or basic level is social payments from the state budget to the poorest (basic pension) without reference to the insurance record or salary. This is the level of poverty eradication.

The first level is the level of a solidarity system in which a generation of working citizens pays contributions to the pension fund and thus generates elderly people who have reached the retirement age.

The second level is the compulsory accumulative. This is a way in which people in the course of their work accumulate contributions in a separate account, from which they then receive a pension. Accumulated contributions invest in various financial instruments. After retirement, the participant receives the right to receive a pension, which is calculated taking into account the accumulated amount of contributions and investment income.

The third level is voluntary accumulative. A future pensioner will accumulate funds on his own. Because he refuses to use these funds now and accumulates them in his retirement future, he will receive certain incentives, for example, tax benefits - they will not pay taxes from these funds.

The fourth level is the municipal pension infrastructure. We are talking about nursing homes, retirement benefits, various types of care ${ }^{14}$.

Such a system, as the world practice has shown, allows us to employ various financial opportunities, thereby contributing to the motivation of earning a future pension.

\subsection{World models of pension benefits}

In countries with developed economies (countries-leaders), classical, social-oriented, and liberal-democratic models are commonly used, while radical-accumulative and accumulative-distribution systems are typical for countries whose economies are on an active stage of development.

In the world experience of retirement, it is accepted to consider several basic models of the pension system. All of them are built on the basis of distribution or accumulation principles, have specific features that are taken into account when developing national models of pension insurance.

\footnotetext{
14 Robert Holzmann, Richard Paul Hinz, Mark Dorfman. Pension Systems and Reform Conceptual Framework Social protection \& Labor. The World Bank. P. 7. URL: http://documents.worldbank.org/curated/en/ 716871468156888545/pdf/461750NWP0Box334081B01PUBLIC10SP00824.pdf
} 
Existing world pension models can be classified as:

- features of the formation of financial resources;

- level of centralization of financial resources;

- structural construction;

- the specificity of countries;

- strategies;

- the level of economic development;

- types of reforms;

- a multi-level model of the World Bank.

By the peculiarities of the formation of financial resources are distinguished:

1) solidarity pension systems - when employees and employers make transfers between generations, that is, they form financial resources for the financing of pensions;

2) capitalized (accumulated) - based on the accumulation of employee financial resources on a personal account during the labour activity and provide for the binding capital markets, through which temporary transfers are carried out. The size of the pension depends on the accumulated amount of money during work.

Pension provision of the world's countries is characterized by structural construction, which forms the basis of state pension provision (basic, social assistance, and minimum pensions), non-state pension provision, as well as additional pension schemes that are able to function at both the state and non-state levels. The level of centralization of financial resources allows the allocation of centralized and decentralized pension systems. Centralization assumes that all responsibility lies with one state or pseudo-state institution that collects all contributions, administers the first and second levels without duplication of functions.

In decentralized models, there are several savings-based pension funds based on individual choices and strengthening regulatory oversight of the system ${ }^{15}$.

The specificity of the countries of the world allows distinguishing the following models of pension insurance:

- Chilean, which is characterized by the payment of contributions only by employees. In Chile, $10 \%$ of the salary is covered by retirement insurance;

\footnotetext{
${ }^{15}$ Nelipovich, O. V. (2009). Pension systems with non-state pension funds in market economies. Bulletin of the Khmelnytsky National University, 2, 58-62.
} 
- Hungarian, where contributions are paid both for mandatory joint and several pension insurance and for non-state pension provision under defined-contribution pension schemes;

- Latvian - with conditional savings accounts;

- Polish, supplementing the previous model. In Poland, until January 1, 1999, there was a conditional accumulation system, and afterward - contributions were paid to private pension funds, from which payers receive real investment income;

- Russian, consisting of basic pension for all citizens, as well as additional pension payments (due to nominal and real investment of pension assets) ${ }^{16}$.

By type of pension reform, distinguish:

1) parametric (non-structural) pension systems, which consist of a change in the deduction and payment scales within the framework of the national pension system. Increasing the length of service, introducing actuarial allowances for early retirement, indexing pensions in response to rising prices, and not wages, are a part of the parametric reform of retirement insurance.

2) nonparametric (structural) - include the replacement of the share of the national pension system with the private sector. Countries such as Hungary, Croatia, Poland, Latvia, and some Latin American countries have implemented structural reforms. Ukraine can also be considered a country for structural reforms in the area of pensions since the basic pension is provided at the state level, while non-state pension funds offer additional pensions.

Pension systems, such as distributive and cumulative, have both advantages and disadvantages. The purpose of the distributive pension system is to implement a mechanism for protection from poverty, but at the same time, it is not adapted to demographic changes. But the main advantage of a distributive pension system is the propensity of insured persons in the long run to risk investment in pension funds and inflation. The purpose of the accumulative pension system is the economic efficiency that is inherent in countries with market economies. The disadvantage of a funded pension system is that it cannot be instantaneously introduced and it has a high sensitivity to changes in financial markets.

\footnotetext{
${ }^{16}$ Grushko, V. I., Grushko, N. V., Bevzenko, O. V., Krasota, O. V., \& Laptev, S. M. (2006). Pension system of Ukraine: Textbook. Kyiv: Condor.
} 
Many countries have introduced a PS with three financial schemes (or tiers). I Tier is the financing of pensions from state pension funds; II Tier - from the state accumulative pension fund; III Tier is non-state pension provision, which involves financing from different sources. That is, these countries have maintained a public distribution system with the simultaneous encouragement of voluntary private pension schemes. In essence, the reform of the PS was aimed at ensuring that the retirement age depended as much as possible on the individual achievements of the employee (insurance period, salary, deductions, and other personal preferences). At present, in most developed countries, citizens' pension benefits come from three sources: state pension funds, corporate sector pensions, and individual pensions received under a voluntary pension accumulation insurance contract. In percentage terms, it is about equal proportions. In many countries, pension provision is mostly provided by non-state pension funds (hereinafter referred to as NPFs) and life insurance companies. Thus, citizens prefer the mechanism of pension insurance to form pensions. In each country, the pension system has its own peculiarities related to the specifics of that SPP model, which has been formed over a decade. Therefore, in some countries, NPFs are preferred, in others - insurance companies or individual programs of saving for the old age. Insurance companies are the main providers of services that allow accumulating the necessary funds upon reaching retirement age. This is explained, first of all, by the peculiarities of taxation of contributions and payments under supplementary pension insurance contracts, which allow either the total or partial exclusion from the tax base of the abovementioned funds. And due to the fact that states are taking less and less part in guaranteeing pension benefits.

Despite the fact that the amount of accumulated assets in NPFs and insurance companies in the developed EU countries is quite significant, they need to allocate additional 456 billion euros in order to preserve the current sizes of state pensions in the next 35 years. Already, the pension burden is $10.4 \%$ of GDP in the fifteen EU countries. In 2040, it will increase to $13.6 \%$. In this regard, the European Commission recommends that EU member states continue to reform pension systems in order to minimize the negative effects of aging and population reduction.

According to the Organization for Economic Cooperation and Development (OECD), in 2013-2015, 26 of 34 countries have made changes to their pension systems. In nine countries, the majority of the 
population was involved in the reform while other changes affected certain groups of employees (for example, private or public sectors) or pensioners themselves.

But the population continues to grow old. The proportion of the population over 65 years old to the engaged people in the world will be doubled by 2050 . This will overload the pension systems and employees who finance their pensions by their work and taxes. The continuation of reforms is inevitable. The question arises as to how and when the countries of the world will carry out this reform. This affects not only the fairness to current and future pensioners but also the state of the economy, both national and world ${ }^{17}$.

There are three ways to reduce government spending for pensions: raising the retirement age, reducing retirement payments and benefits, and raising taxes. Solidarity PS reforms are usually aimed at reducing pension payment. This increases the need to develop private pension provision and its role in future retirement income. All OECD countries have accumulative pension systems. On average, in 34 countries, the distributive part provides a pension in a $41 \%$ average salary, with the accruals being increased to $58 \%$, that is, about one-third of the pension is provided by savings ${ }^{18}$.

In general, measures taken by many OECD countries are aimed at reducing retirement expenditures and at parametric reforms. For example, the Czech Republic and Finland reduced indexation, France changed its order, Greece and Belgium froze it. Since 2017, Slovakia tied indexation to inflation (earlier - to inflation rates and wage growth), Sweden, Finland, Portugal, and Germany applied the same rules. In Turkey, indexation depends on GDP rates. Luxembourg indexes pensions only if pension income exceeds costs. Some recent political reforms were aimed at delaying retirement, others - vice versa. The pension age is rising massively. By 2015, 30 out of 34 OECD countries have made an increase. Most countries have gone through a gradual increase in pension age.

For example, in France, in 2010, an increase took place in the pension age from 60 to 62 years to 2018, to 2030 - to 67 years, and the minimum required period of payment of contributions will gradually be

\footnotetext{
17 Tuladkhar, A., Pereyra, Zh., Muir, D., \& Karam, F. (2011). Globalnaya pensionnaya reforma [Global Pension Reform]. Retrieved from: http://www.mn.ru/newspaper/opinions/71478

${ }^{18}$ Kuvshynova, O. (2016). Kak mir reformiruyet svoi pensionnyye sistemy [How the world is reforming its pension systems]. URL: https://www.vedomosti.ru/economics/articles/2016/12/23/670920-mirreformiruet
} 
raised from the current 41.5 years to 43 . Canada, Belgium, and Spain announced on the gradual increase in the retirement age to 67 years old, in Germany it raises from 65 to 67 per month in a year, in the Netherlands it will reach 67 years in 2021, and in Australia it will reach this number in 2023. In countries with economies in transition, where the retirement age was 60 years for men and 55 for women in the mid1990s, it now stands at 65 and 63, respectively (Kuvshynova, 2016). Hungary increases the age from 62 to 65 years. In the Czech Republic, they will retire at the age of 68. In Slovenia, where the retirement age is one of the lowest -58 , it raises to 60 for those who paid contributions for 40 years, if less - to $65^{19}$.

Improving the pension system in Ukraine is a top priority, so the foreign experience is very useful. Ukraine has the first and third levels PS. The deficit of the Pension Fund of Ukraine is covered from the state budget. Now it is more than 140 billion UAH, which is much more than the state's expenditures on education, science, and culture together. The pension benefits of the main part of pensioners are low. However, in our opinion, shifting the retirement burden to just one employee is unacceptable; this may increase retirement poverty over the long term. After all, the pensions of most citizens are low. In favour of raising the retirement age for women in 2011, the following "argument" worked: in Ukraine, women after retirement live much longer than men. Moreover, the fact that a large number of Ukrainian women not only work but also do a lot as housewives and raise children was not taken into account.

In Ukraine, a situation has arisen, in which, in the medium term, the fulfilment of state pension obligations is possible only due to state borrowing increase. Therefore, maintaining the sustainability of the state budget requires a change in the financial model of the Ukrainian pension system. After attainment of independence in Ukraine, efforts were made to reform the pension system in various years - the transition from pension provision to pension insurance (2004), raising the pension age and extending the minimum period of insurance to obtain a pension (2011), introducing new rules for the calculation of pensions, modernization of pension payments, etc. (2017). However, the process of creating an optimal model of financial support for PS is not over. The ultimate goal of pension reform is to ensure long-term macroeconomic and social stability in the state and improve the pensioners' well-being.

${ }^{19}$ Ibid. 
The reform is a part of the current macroeconomic policy of the state, which is aimed at a progressive restructuring in order to comply with general socio-economic norms. The multi-level pension system protects many risks, especially from the general risks arising from the economy and politics. Therefore, one of the tasks of the strategy of the development of the pension system of Ukraine is to determine the optimal proportions and accrual principles of pension provision. The main question is how to change the model between the state, employers, and employees.

\section{CONCLUSIONS}

Pension provision of citizens is one of the most important social functions of the state. It should be noted that from how effectively the PS works, one can judge the level of socialization of the country's economy. The PS is also a kind of barometer of the health of the state finance system. The last few decades in the world there are global changes that negatively affect the financing of pensions. First of all, it is an ageing of the population. It takes place against the background of declining birth rates, large-scale migration of the population, structural changes in national economies, and the like. The effects of population ageing are exacerbated by problems with public finances after the global financial crisis of 2008-2009. The reform of the pension system by many European countries is aimed at ensuring its future sustainability.

Currently, Ukraine has the first and third levels PS. The deficit of the Pension Fund of Ukraine is covered from the state budget. Now it is more than 140 billion UAH, which is much more than the state's expenditures on education, science, and culture together. The pensions of the main part of pensioners are low. The world standard of replacement rate cannot be sustained. In a difficult financial situation, the government is limited in its ability to cover the deficit of PFCs at the expense of public funds. All this suggests that the Ukrainian pension system needs radical reform, first of all, the transition to a three-tier system. The government announced a gradual introduction of the accumulation (second) level of the pension system from 2020. It is extremely important that this innovation is supported by the development of the stock market and the growth of incomes of Ukrainian citizens. Government officials expect that the deficit of PFC will gradually decrease, in 2026 the turning point will come and in 2027 the budget of the fund will be deficit-wise ${ }^{20}$.

\footnotetext{
${ }^{20}$ Kalacheva, G. Pension reform suffered by competitors. What is waiting for her in autumn? URL: https://www.epravda.com.ua/publications/2017/07/25/627399/
} 


\section{SUMMARY}

The article analyses the development of pensions in the world and the problems of its implementation in the context of global risks. The main reasons for which the pension is considered as a global problem are named. It is noted that the negative manifestations of globalization are inherent in the Ukrainian practice of pension provision. The aim of the work is to study the global experience of reforming national pension systems in the face of growing global negative trends. The study was conducted using the methods of scientific knowledge: comparison and synthesis - to identify significant differences in approaches to the study of globalization processes; analysis and synthesis - identifying patterns of economic development and determining their social consequences; historical and logical, as well as statistical methods. The article discusses the experience of some countries in improving the practice of pensions. It has been established that pension reforms are aimed at ensuring that the individual achievements of an employee (pension insurance, salary, deductions, other personal preferences) are taken into account as much as possible. In most developed countries, pensions are funded from three sources: state pension funds, corporate sector pensions, and individual pensions that a pensioner receives under a personal voluntary retirement savings policy. Further development of the pension system in Ukraine should be ensured through the introduction of its second level. The study found that global problems have a particular negative impact on retirement benefits. The search for ways to neutralize or mitigate the effects of global problems has led many countries to introduce a threetier pension system that provides funding from various sources. The World Bank proposes to introduce a five-tier pension system. Since raising the retirement age cannot be infinite, pension systems must be multivariately constructed.

\section{REFERENCES}

1. Meadows, D. H., Meadows, D. L., Randers, J., \& William, W. Behrens III (1972). The limits to growth. A Report for the Club of Rome's Project on the Predicament of Mankind. New York: Universe Books.

2. Whitehouse, E. (2007). Pension Panorama: Retirement-Income Systems in 53 Countries. Washington, DC: The World Bank. URL: http://www.biomedsearch.com/article/EdwardWhitehousePension-PanoramaRetirement/210033207.html 
3. Kotlikoff, L., \& Burns, S. (2005). Pensionnaya sistema pered burey: to, chto nuzhno znat kazhdomu o finansovom budushchem svoyey strany [Pension system before the storm: what you need to know about each other about the financial future of your country]. Moscow: Alpina Biznes Buks. (in Russian)

4. Akbulatov, R. S. (2013). Istoriya stanovleniya i razvitiya pensionnoy sistemy Krasnoyarskoyo kraya v 90-e gg. XX v. - nachalo XXI v. [The history of the formation and development of the pension system of the Krasnoyarsk Territory in the 90s. XX - the beginning of the XXI century]. Thesis. Irkutsk. (in Russian)

5. Antropov, V. V. (2006). Sotsyalnaya zashchita v stranakh Evropeyskogo Soyuza. Istoriya, organizatsiya, finansirovaniye, problem [Social protection in the European Union. History, organization, financing, problems]. Moscow: Izd-vo Ekonomika. (in Russian)

6. Tserkasevich, L. V. (2002). Sovremennyye tendentsii sotsialnoy politiki $\mathrm{v}$ stranakh Evropeyskogo Soyuza [Modern trends in social policy in the European Union]. St. Petersburg. (in Russian)

7. Haidar, E. (2004). Istoriya pensiy [The history of pensions]. URL: http://www.ng.ru/ ideas/2004-07-13/10_histori.html (in Russian)

8. Dynkin, A. A. (Ed.) (2007). Mirovaya ekonomika: prognoz do 2020 goda [World Economy: Forecast until 2020]. Moscow: Mahistr. (in Russian)

9. Bilorus, O., \& Matseiko, Yu. (2002). My mohly b buty sered lideriv [We could be among the leaders]. Holos Ukrainy, March 1, 6. (in Ukrainian)

10. Tanzi, V., \& Schuknecht, L. (2000). Public Spending in the $20^{\text {th }}$ Century. A Global Perspective. Cambridge and New York: Cambridge University Press.

11. Melbourne Mercer Global Pension Index 2018. P. 3. URL: https://australiancentre.com.au/wp-content/uploads/2018/10/MMGPIReport-2018.pdf

12. Karachurina, L. (2009). Germanyia: kak upravliat migrantami [Germany: how to manage migrants]. Sovremennaya Yevropa, 2, 18-33. (in Russian)

13. Ivanova, E. I., \& Sidornia, A. A. (2014). Mirovoy opyt razvitiya pensionnykh sistem: obshchemirovyye tendentsii i mezhstranovyye razlichiya [World experience in the development of pension systems: global trends and differences between countries]. Molodezhnyy 
nauchnyy forum: Obshchestvennyye i ekonomicheskiye nauki. URL: https://nauchforum.ru/studconf/social/viii/23188 (in Russian)

14. Pensions at a Glance 2013. OECD and G20 Indicators. URL: http://www.oecd.org/pensions/publicpensions/OECDPensionsAtAGlance2013.pdf

15. Holzmann, R., Hinz, R. P., Dorfman M. Pension Systems and Reform Conceptual Framework Social protection \& Labor. The World Bank. URL: http://documents.worldbank.org/curated/en/7168714681568 88545/pdf/461750NWP0Box334081B01PUBLIC10SP00824.pdf

16. Nelipovich, O. V. (2009). Pensiini systemy $z$ uchastiu nederzhavnykh pensiinykh fondiv $\mathrm{v}$ krainakh $\mathrm{z}$ rynkovoiu ekonomikoiu [Pension systems with non-state pension funds in market economies]. Visnyk Khmelnytskoho natsionalnoho universytetu, 2, 58-62. (in Ukrainian)

17. Grushko, V. I., Grushko, N. V., Bevzenko, O. V., Krasota, O. V., \& Laptev, S. M. (2006). Pensiyna systema Ukrainy [Pension system of Ukraine]: Textbook. Ed. V.I. Grushko. Kyiv: Condor. (in Ukrainian)

18. Kalacheva, G. Pensiinu reformu spitkaly konkurenty. Shcho na nei chekaie voseny? [Pension reform suffered by competitors. What is waiting for her in autumn?]. URL: https://www.epravda.com.ua/ publications/2017/07/25/627399/ (in Ukrainian)

19. Tuladkhar, A., Pereyra, Zh., Muir, D., \& Karam, F. (2011). Globalnaya pensionnaya reforma [Global Pension Reform]. URL: http://www.mn.ru/newspaper/opinions/71478 (in Russian)

20. Kuvshynova, O. (2016). Kak mir reformiruyet svoi pensionnye sistemy [How the world is reforming its pension systems]. URL: http://www.vedomosti.ru/economics/articles/2016/12/23/670920mirreformiruet (in Russian)

Information about the author: Barannik L. B.

Doctor of Economics, Professor, Head of the Department of Taxation and Social Security, University of Customs and Finance, Ukraine 